\title{
Energy nutritional requirements for females of Nellore, Nellore $\times$ Angus and Nellore $\times$ Simmental fed on two forage:concentrate ratios ${ }^{1}$
}

\section{Evaristo Jorge Oliveira de Souza ${ }^{2}$, Sebastião de Campos Valadares Filho ${ }^{3}$, Adriana Guim², Rilene Ferreira Diniz Valadares ${ }^{3}$, Marcos Inácio Marcondes ${ }^{3}$, Antonia Sherlânea Chaves Véras $^{2}$, Paloma de Melo Amaral ${ }^{3}$, Tathyane Ramalho Santos ${ }^{3}$}

\author{
${ }^{1}$ Financianed by Fundação de Amparo à Pesquisa de Minas Gerais-FAPEMIG/Conselho Nacional de Pesquisa - CNPq. \\ 2 Universidade Federal Rural de Pernambuco. \\ ${ }^{3}$ Universidade Federal de Viçosa.
}

\begin{abstract}
The objective of this study was to determine the energy nutritional requirements for females of Nellore, Nellore $\times$ Angus and Nellore $\times$ Simmental fed on two levels of concentrate. Sixty heifers from three genetic groups were used: 20 Nellore, 20 Nellore $\times$ Angus and 20 Nellore $\times$ Simmental. Twelve belonged to the reference group (four of each genetic group) and were slaughtered at the beginning of the experiment. Another 12 heifers (four of each genetic group) were fed on the maintenance level and 36 heifers (12 animals of each genetic group) were kept in feeding system ad libitum with 30 (six in each group) or $50 \%$ (six of each group) dry matter concentrate. Animals were randomly assigned to six treatments in a $3 \times 2$ factorial arrangement (three genetic groups and two diets) with six replicates per treatment. Nine more heifers were used in a parallel experiment to estimate the apparent digestibility coefficients (three from each genetic group). Net energy requirements were estimated by the equation of retained energy as a function of metabolic empty body weight $\left(\mathrm{EBW}^{0.75}\right)$ and empty body weight gain (EBWg). Requirements of metabolizable and net energy were estimated for maintenance by the equation of heat production as a function of metabolizable energy intake. Using the combined equation RE (retained energy; Mcal/day) = $0.0703 \times \mathrm{EBW}^{.75} \times \mathrm{EBWg}^{1.128}$ to predict net energy requirements for weight gain is recommended. The requirement of metabolizable and net energy for maintenance of all groups is 70.55 and $106.53 \mathrm{kcal} / \mathrm{kgEBW}^{0.75} /$ day, respectively. Use efficiencies of metabolizable energy for gain and maintenance are 36.41 and $66.23 \%$, for the three genetic groups respectively.
\end{abstract}

Key Words: crossbred heifers, maintenance, metabolizable energy, net energy

\section{Introduction}

The national livestock has gone through difficult times, despite its extensive herd (near 200 million heads) and being the largest meat exporter. Challenges posed by globalization force producers to increasingly accelerate the rhythm of animal growth in order to obtain a higher turnover of capital and thereby promote greater intensification of the production system.

The use of taurine breeds, presumably with greater growth potential for producers and technicians, can be an alternative to reduce the time spent by animals on farm and increase the use rate. However, the lack of adaptability of these breeds to the climate of much of Brazil makes it difficult to use. Thus, the use of $\mathrm{F}_{1}$ Bos taurus taurus/Bos indicus females increases the possibility of exploring the desired characteristics of both breeds, in addition to possible increase in the gain, i.e., gain increase provided by the taurine breeds and adaptation to the tropics offered by zebu.

Assessments of different genetic groups regarding performance, body composition and nutritional requirements are critical to the development of feeding patterns and models that help producers to conduct nutritional programs in Brazil. Several studies have been conducted in a large research on cattle body composition to estimate their nutritional requirements and growth efficiency. However, most studies do not use females.

Therefore, this study aimed to determine the nutritional requirements of energy for females of Nellore, $F_{1}$ Nellore $\times$ Angus and Nellore $\mathrm{F}_{1}$ Simmental.

\section{Material and Methods}

The study was conducted at the Departament of Animal Science of the Universidade Federal Viçosa, MG. The experiment lasted 142 days: 30 days for adaptation of animals to experimental conditions and 112 days for data collection.

Sixty heifers from three genetic groups with 18 months of age were used: 20 Nellore with average $247.80 \pm 16.71 \mathrm{~kg}$; $20 \mathrm{~F}_{1}$ Nellore $\times$ Angus with average of $292.94 \pm 17.85 \mathrm{~kg}$ and $20 \mathrm{~F}_{1}$ Nellore $\times$ Simental with average of $258.64 \pm 34.06 \mathrm{~kg}$. 
Four animals from each genetic group were slaughtered at the end of the adaptation period (reference group) to estimate initial body composition and empty body weight (EBW) of animals distributed in the treatments.

From the total number of heifers, 12 (four of each genetic group) were fed on the maintenance level $(1.1 \%$ body weight in dry matter) with diets containing $30 \%$ concentrate and 36 heifers (12 animals of each genetic group) were kept in feeding system ad libitum with 30 (six in each group) or 50\% (six from each group) dry matter (DM) of feed concentrate. Nine heifers were used in parallel to the experiment to estimate the apparent digestibility coefficients (three from each genetic group).

Experimental diets were composed of corn silage, corn meal, soybean meal, livestock urea, sodium bicarbonate, magnesium oxide, mineral mixture and sodium chloride (Tables 1 and 2).

Heifers were randomly assigned to six treatments (completely randomized design) in a $3 \times 2$ factorial arrangement, with three genetic groups and two diets (low and high proportion of concentrate ad libitum), with six replicates per treatment. Animals were housed in individual cages equipped with concrete feeder and drinker.

Animals were fed twice a day ( 8 and $16 \mathrm{~h}$ ) and adjusted daily, allowing around 5\% surplus of supplied and water permanently available to the animals.

For determination of weight gain, heifers were weighed every 28 days. Samples of concentrates, silage corn and surplus from each animal were collected daily. Samples were grouped proportionally in each period of 28 days making composite samples, which were pre-dried in forced ventilation oven at $65{ }^{\circ} \mathrm{C}$ and ground in a mill with a $1-\mathrm{mm}$ mesh sieve for subsequent laboratory analyses.

After the experimental period, slaughters began with 6 animals a day (one of each genetic group and concentrate level), with one-day interval for carcasses dissection between each slaughter.

Before slaughter, animals were fasted for 16 hours of solid. Slaughter was carried out via stunning and jugular section for total bleeding, the gastrointestinal tract (rumen, reticulum, omasum, abomasum and small and large intestines) of each animal was emptied, washed and weighed.

Weight of heart, lungs, liver, spleen, kidneys, internal fat, industrial meat, mesentery, tails and trimmings (esophagus, trachea and reproductive system) and washed gastrointestinal tract were added to the other body parts (carcass, head, leather, feet and blood) for determination of empty body weight (EBW).

The estimated initial EBW of animals that remained under feeding was obtained by the ratio between EBW and body weight (BW) of reference animals.

Within each treatment (genetic group and diet), two animals were randomly selected, which had head and limbs (anterior and posterior) sampled for subsequent physical separation of muscles, fat, bones and leather. The average composition of head and limbs of these animals was used to estimate the composition of animals that did not have their limbs and head sampled.

After slaughter, the carcass of each animal was divided into two half-carcasses, which were weighed and then cooled in a cold chamber at $-5{ }^{\circ} \mathrm{C}$ for 18 hours. Subsequently, all right half-carcasses were separated into muscle, fat and bones, ground, and sampled for direct determination of protein and fat.

The rumen, reticulum, omasum, abomasum, small intestine, large intestine, internal fat, mesentery, liver, heart, kidney, lung, tongue, spleen, industrial meat and trimmings were crushed in industrial cutter for 20 minutes to remove a homogeneous sample of organs and viscera. Blood samples were collected immediately after slaughter, packed in glass container and oven-dried $\left(65^{\circ} \mathrm{C}, 72\right.$ hours) for determination of DM content, then ground in a ball mill and stored into containers for analysis of dry matter, ash, total nitrogen and ether extract as described by Silva \& Queiroz (2002); the crude protein content was obtained by the product between total nitrogen and factor 5.88 as suggested by Baldwin (1995).

Table 1 - Chemical composition of feedstuffs

\begin{tabular}{|c|c|c|c|}
\hline Nutrients & \multicolumn{3}{|c|}{ Feed } \\
\hline Dry matter (DM),\% & 28.27 & 87.93 & 87.36 \\
\hline Crude protein, \%DM & 6.96 & 8.27 & 51.95 \\
\hline Ether extract, \%DM & 2.52 & 4.15 & 3.71 \\
\hline Neutral detergent fiber (NDF), \%DM & 50.82 & 10.83 & 15.18 \\
\hline
\end{tabular}


Table 2 - Proportion of ingredients, percentage and nutritional composition of experimental diets

\begin{tabular}{|c|c|c|}
\hline \multirow{2}{*}{ Ingredients $(\%$ of dry matter, DM) } & \multicolumn{2}{|c|}{ Concentrate levels } \\
\hline & $30 \%$ & $50 \%$ \\
\hline Corn silage & 69.10 & 50.00 \\
\hline Corn meal & 23.37 & 38.95 \\
\hline Soybean meal & 5.49 & 9.16 \\
\hline Urea + ammonium sulfate & 1.14 & 0.40 \\
\hline Sodium chloride & 0.30 & 0.50 \\
\hline Mineral mixture ${ }^{1}$ & 0.30 & 0.50 \\
\hline Magnesium oxide & 0.10 & 0.17 \\
\hline Sodium bicarbonate & 0.20 & 0.33 \\
\hline Nutrients & \multicolumn{2}{|c|}{ Nutritional composition } \\
\hline Dry matter (DM),\% & 38.11 & 45.35 \\
\hline Organic matter, \%DM & 94.99 & 94.96 \\
\hline Ether extract, \%DM & 2.92 & 3.21 \\
\hline Crude protein, \%DM & 12.46 & 12.42 \\
\hline Metabolizable energy, Mcal $/ \mathrm{kgDM}^{2}$ & 2.35 & 2.67 \\
\hline Neutral detergent fiber (NDF), \%DM & 38.48 & 30.84 \\
\hline $\mathrm{NDF}$ corrected for ash and protein, $\% \mathrm{DM}$ & 134.85 & 27.89 \\
\hline Non-fibrous carbohydrates, \%DM & 46.50 & 52.04 \\
\hline
\end{tabular}

With the exception of blood, samples from organs plus viscera, muscle plus fat of the right half-carcass, leather and bones were lyophilized. Subsequently, samples were subjected to successive washings with petroleum ether, resulting in pre-defatted dry matter. Afterwards, samples were ground in ball mill for subsequent determination of dry matter, ash, total nitrogen and ether extract as described by Silva \& Queiroz (2002), with crude protein content obtained by the product between total nitrogen and factor 5.88 as suggested by Baldwin (1995).

The determination of body energy was obtained from the body contents of fat and protein and their respective caloric equivalents, according to the equation recommended by ARC (1980): $\mathrm{EC}=5.6405 \mathrm{x}+9.3929 \mathrm{Y}$, where $\mathrm{EC}$ is the energy content (Mcal), $\mathrm{x}$ is the body protein $(\mathrm{kg})$ and $\mathrm{Y}$ stood for body fat $(\mathrm{kg})$. Energy contents in body of animals in each treatment and all treatments combined were estimated by nonlinear equations of body energy contents of animals in performance and reference, depending on the EBW as the following model: $\mathrm{EC}=\beta_{0} \times \mathrm{EBW}{ }^{\beta 1}$, where $\mathrm{EC}$ is the body energy content (Mcal), EBW is empty body weight and $\beta 0$ and $\beta 1$ are regression parameters.

From the regression parameters presented above, net requirements of energy per pound of gain in empty body weight were estimated by the derivative equation above, according to the model $\mathrm{NEg}=\beta_{0} \times \beta_{1} \times \mathrm{EBW}^{\beta 1-1}$, where $\mathrm{NE}_{\mathrm{g}}$ is the net energy requirement of net energy for gain (Mcal $/ \mathrm{kgEBWg}$ ). For the conversion of heat production into EBW were calculated ratios between the EBW and heat production of animals kept in the experiment, within each genetic group, which were then used to convert requirements to gain in EBW into gain requirements for heat production.

Regression equations were fitted between the retained energy (RE Mcal/day) and EBW daily gain (EBW, $\mathrm{kg}$ /day) for a given metabolic EBW $\left(\mathrm{kg}^{0.75}\right)$ from the nonlinear models method (PROC NLIN SAS), using the iterative algorithm for Gaus-Newton: $\mathrm{RE}=\beta_{2} \times \mathrm{EBW}^{0.75} \times \mathrm{EBWg} \beta 1$

Net energy requirements for maintenance were estimated by the $\beta 0$ coefficient of the non-linear regression equation relationship between heat production (HP, Mcal $/ \mathrm{kg}$ $\mathrm{EBW}^{0.75}$ ) and metabolizable energy intake (MEI, Mcal $/ \mathrm{kg}$ PCVZ0.75), according to Ferrell \& Jenkins (1998): $\mathrm{PC}=\beta_{0} \times \mathrm{e}^{\beta 1 \times \mathrm{MEI}}$. The metabolizable energy requirements for maintenance were estimated from the relationship between retained energy ( $\mathrm{RE}, \mathrm{Mcal} / \mathrm{kg} \mathrm{EBW}^{0.75}$ ) and metabolizable energy intake ( $\mathrm{Mcal} / \mathrm{kg} \mathrm{EBW}^{0.75}$ ), according to the model: $\mathrm{RE}=\beta_{1} \times \mathrm{MEI}+\beta_{0}$, where $\beta 1$ represents the use efficiency of metabolizable energy for weight gain. Equating RE to zero in the equation above, the energy consumption in which energy retention is null was obtained, representing thus the requirements of metabolizable energy for maintenance (MEm). Thus, the metabolizable energy for maintenance was obtained by the ratio between the coefficients $\beta 0$ and $\beta 1$ form the equation above $(\mathrm{MEm}=\beta 0 / \beta 1)$.

To obtain parameters $\beta 0$ and $\beta 1$ from the equation above, the method of orthogonal regression was used, as recommended by Fuller (1987), since it was assumed that there are errors associated with two variables (RE and MEI). Equation parameters were obtained as follows: $\left.\beta_{0}=\bar{Y}-\beta_{1} \bar{X} ; \beta_{1}=\left(\sigma_{y}^{2}-\sigma_{x}^{2}+\left(\left(\sigma_{y}^{2}-\sigma_{x}^{2}\right)^{2}+4 \sigma_{x y}{ }^{2}\right)^{\wedge 0.5}\right)\right) /$ $2 \sigma_{x y}$, where $x$ is the average consumption of metabolizable energy, $\mathrm{Y}$ is the average energy retained, $\sigma^{2}{ }_{\mathrm{x}}$ is the variance of $\mathrm{x}, \sigma_{\mathrm{y}}^{2}$ is the variance of $\mathrm{Y}$ and $\sigma_{\mathrm{xy}}$ is the covariance between $\times$ and $\mathrm{Y}$.

For calculation of partial use efficiencies of metabolizable energy for synthesis of fat and protein, the equation was assembled: $\mathrm{MEI}=\beta_{0}+\beta_{1} \times \mathrm{ER}_{\text {prot }}+\beta_{2} \times \mathrm{RE}_{\text {fat, }}$, where MEI is the daily metabolizable energy intake (Mcal/EBW ${ }^{0.75} /$ day), $\mathrm{RE}_{\text {prot }}$ and $\mathrm{RE}_{\text {fat }}$ are the amount of energy retained as protein and fat (Mcal/EBW ${ }^{0.75} /$ day), respectively, and $\beta 0$, $\beta 1$ and $\beta 2$ are the multiple regression coefficients. The equation intercept $(\beta 0)$ represents a third way to estimate the metabolizable energy requirements for maintenance (Mcal/EBW $\left.{ }^{0.75}\right)$, and inverse coefficients $\beta 1(1 / \beta 1)$ and $\beta 2$ $(1 / \beta 2)$ represented the efficiencies of energy deposition as protein and fat $\left(\mathrm{k}_{\text {prot }}\right.$ and $\left.\mathrm{k}_{\mathrm{fat}}\right)$, respectively (Valadares Filho et al., 2005). 
Digestibility of experimental diets was estimated by conducting a digestibility bioassay performed in three Latin squares $(3 \times 3)$; one square for each genetic group, consisting of three heifers, three experimental periods of 28 days and three diets (low and high proportion of concentrate ad libitum and low proportion of concentrate to the maintenance level). In the third week of each experimental period (Latin square) the total collection of feces of three consecutive days was performed to estimate the apparent digestibility of nutrients, contents of total digestible nutrients (TDN) and metabolizable energy (ME) of diets. The conversion of digestible energy (DE) in metabolizable energy was in accordance with the NRC (2000), according to the equation $\mathrm{ME}=0.82 * \mathrm{DE}$ (considering that a pound of TDN is equal to $4.409 \mathrm{Mcal} \mathrm{DE}$ ).

Samples of corn silage, concentrate ingredients (corn, soybean meal, urea and minerals), remainders and feces were analyzed in the laboratory and their dry matter (DM), mineral matter (MM) crude protein (CP), ether extract (EE) and neutral detergent fiber (NDF) contents, using methods described by Silva \& Queiroz (2002). The Ankom ${ }^{\circledR}$ system was used to assess NDF, with modification of the bag used $(5.0 \times 5.0 \mathrm{~cm}, 100 \mu \mathrm{m}$ porosity), which was made using non-woven fabric - TNT $\left(100 \mathrm{~g} / \mathrm{m}^{2}\right)$.

For quantification of total carbohydrates (QTC), the following equation was used: QTC $=100-(\% \mathrm{CP}+\% \mathrm{EE}+\%$ Ash), as Hall et al. (1999). Due to the presence of urea in the diets, contents of non-fiber carbohydrates (NFC) were estimated according to Hall (2000): NFC $\%=100-[(\% \mathrm{CP}-$ $\%$ CP Urea $+\%$ Urea) $+\%$ NDF $\%+\%$ EE $+\% \mathrm{MM})]$. For estimation of total digestible nutrients (TDN) the equation described by Weiss (1999) was used, in which TDN $=$ DCP $+\mathrm{DEE}^{*} 2.25+\mathrm{DNFC}+\mathrm{NDF}_{\mathrm{ap}}$, where DCP, DEE, DNFC and NDFap mean, respectively, digestible crude protein, digestible ether extract, digestible non-fibrous carbohydrates and neutral detergent fiber (corrected for ash and protein).

Results were analyzed statistically by analysis of variance and regression using the statistical package SAS (Statistical Analysis Systems, version 9.2) Comparisons between regression equations of parameters evaluated for each treatment were performed according to the methodology recommended by Regazzi (1996) to test for models identity.

\section{Results and Discussion}

The ratio between body weight (BW) and empty body weight (EBW) to estimate EBW did not affect $(\mathrm{P}>0.05)$ concentrate level, genetic group or the concentrate level $\times$ genetic group interaction. Thus, the EBW from the $\mathrm{BW}$ of animals in this study can be estimated as follows: $\mathrm{EBW}(\mathrm{kg})=0.91( \pm 0.018) \times \mathrm{BWF}(\mathrm{kg})$, where $\mathrm{BWF}$ is body weight at fast.

This ratio (EBW/BW) is consistent with data reported in the literature, which can vary from 0.85 to 0.95 (NRC, 2000; Backes et al., 2002; Paulino et al. 2004; Valadares Filho et al., 2006; Chizzotti et al., 2008).

The ratio between average daily gain (ADG) and gain in empty body weight (EBW) necessary for conversion of requirements into $\mathrm{EBW}$ gain in requirements for $\mathrm{BW}$ also did not affect the concentrate level, genetic group or concentrate level $\times$ genetic group interaction $(\mathrm{P}>0.05)$. Therefore, the combined equation is shown as follows: $\mathrm{EBW}(\mathrm{kg} /$ day $)=0.90( \pm 0.050) \times \mathrm{ADG}(\mathrm{k} /$ day $)$. To obtain the requirements for net daily gain of $1 \mathrm{~kg} \mathrm{BW}$ under this study conditions, one must multiply the gain requirements of $1 \mathrm{~kg}$ EBW by 0.90 . Result similar to 0.90 for Nellore (integrate males, castrated males and females), found by Paulino et al. (2004). However, this factor is below the 1.006 and 0.96 found by Silva et al. (2002) and Valadares Filho et al. (2010), respectively, who worked with zebu animals and their crossings. It is noteworthy that these last authors worked mostly on males and they have greater potential for weight gain and carcass yield when compared with females (Coutinho Filho et al., 2006).

Equations that describe the estimate body energy content were:

Nellore $>$ Body energy $($ Mcal $)=0.076 \times \mathrm{EBW}^{1.6424}$; Nellore $\times$ Angus $>$ Body Energy $(\mathrm{Mcal})=0.082 \times \mathrm{EBW}^{1.6015}$; Nellore $\times$ Simmental $>$ BodyEnergy $(\mathrm{Mcal})=0.048 \times \mathrm{EBW}^{1.7075}$.

There were no significant differences between groups $(\mathrm{P}>0.05)$, therefore, a combined equation was generated, described as: Body Energy $(\mathrm{Mcal})=0.204 \times \mathrm{EBW}^{1.4566}$. This behavior can be best viewed in the ratio between the content of body energy as function of increasing body weight for the three genetic groups evaluated (Figure 1).

From the equations presented, net energy requirements per pound of gain in empty body weight for different body weights were estimated (Table 3 ).

Data show increase in energy requirements as body weight of animals increases. This is due to the increasing maturity of animals. According to Luchiari Filho (2000), as the animal approaches maturity, point at which muscle tissue deposition ceases, there is more fat deposition (more body energy) in the body of the animal.

It is noteworthy that no difference in energy requirements for gain in the different genetic groups had been expected, since there was no difference in the body energy content of animals for different EBW (Figure 1). This behavior is consistent with Berndt et al. (2002). The 
authors reported that nutritional requirements of animals are directly influenced by their body composition.

Paulino et al. (1999), working on net energy requirement for weight gain of four zebu breeds (Nellore, Gir, Guzerat and Tabapuã) also found no differences between the breeds studied.

According to Siqueira et al. (2007), the energy requirement of cattle varies between genetic groups. However, this statement reported by the aforementioned authors does not corroborate the results of this research. The lack of significance is related to the little genetic difference of animals studied, since "a genetic half" of the three groups is Nellore and is being compared only with the "other half" Nellore, Angus and Simmental, i.e., the possible difference existing has been diluted. Thus, despite the high heterosis, zebu animals could get gain similarly to crossbreds if fed properly.

From the data obtained on retained energy (RE, Mcal/ day), empty body weight $\left(\mathrm{EBW}^{0.75}, \mathrm{~kg}^{0.75}\right)$ and empty body weight gain (EBWg, kg/day) of animals, equations to estimate the retained energy from these two parameterswere constructed: Nellore $>$ RE $($ Mcal/day $)=0.0773 \times \mathrm{EBW}^{0.75} \times$

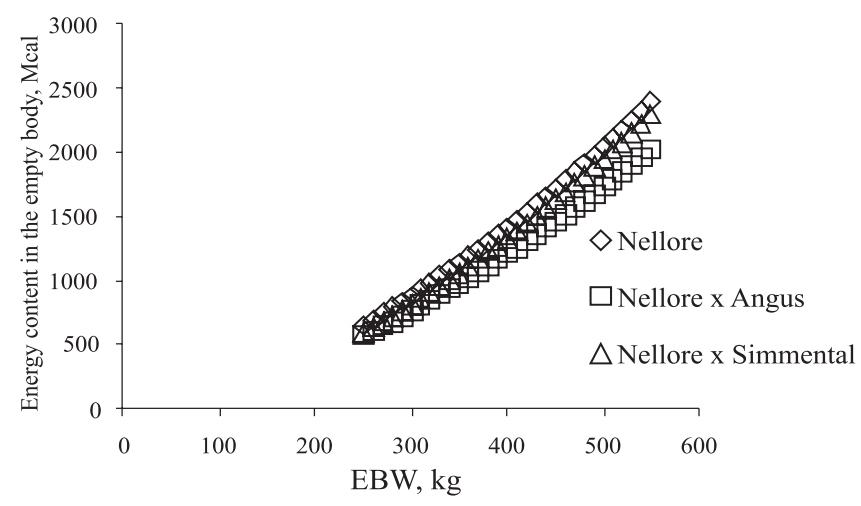

Figure 1 - Energy content in the empty body for different weights of empty body (EBW) for the three genetic groups evaluated.
$\mathrm{EBW}^{1.063}$; Nellore $\times$ Angus $>$ RE $($ Mcal/day $)=0.0623 \times$ $\mathrm{EBW}^{0.75} \times \mathrm{EBWg}^{1.065}$; Nellore $\times$ Simmental $>\mathrm{RE}($ Mcal $/$ day $)=$ $0.0769 \times \mathrm{EBW}^{0.75} \times \mathrm{EBWg}^{1.327}$. However, there were no significant differences between the genetic groups $(\mathrm{P}>0.05)$ using the combined equation described: $\mathrm{RE}(\mathrm{Mcal} /$ day $)=$ $0.0703 \times \mathrm{EBW}^{0.75} \times \mathrm{EBWg}^{1.128}$.

Note that the EBW exponents were higher when comparing the equation $\mathrm{RE}(\mathrm{Mcal} / \mathrm{day})=0.0635 \times \mathrm{EBW}^{0.75}$ $\times$ EBWg ${ }^{1.097}$ of NRC (2000) and Valadares Filho et al. (2006): $\mathrm{RE}(\mathrm{Mcal} /$ day $)=0.0735 \times \mathrm{EBW}^{0.75} \times \mathrm{EBWg}^{1.0996}$ (females). It is noteworthy that the last authors refer to the first version of the Brazilian table of nutritional requirements for zebu animals - database composed of Nellore animals and their crosses with Holstein, Simmental, Limousin, Marchigiana, Angus and Brangus and bi-crossed breeds. Taking a $350 \mathrm{~kg}$ body weight-female as basis with $1 \mathrm{~kg}$ daily gain of body weight, when calculating from the equation obtained in this study, there are values of $4.71 \mathrm{Mcal} /$ day retained energy. If this same calculation is made from the equation adopted by Valadares Filho et al. (2006) and NRC (2000), there will be 5.95 and $6.06 \mathrm{Mcal} /$ day for retained energy values, respectively.

Net energy requirements for maintenance are represented by the energy expended in basal metabolism and heat produced by voluntary activities of the animal. According to Caton et al. (2000), breeding herd consumes about 65 to $75 \%$ of the total energy required by the system of meat production as a whole. Thus, over $50 \%$ of energy used for meat production is used only for maintenance of cows. By the exponential ratio of heat production (HP) and metabolizable energy intake of animals in the maintenance group plus performance animals was obtained the following equations: Nellore $>$ BW $\left(\mathrm{kcal} / \mathrm{kgEBW}^{0.75} /\right.$ day $)=65.273 \mathrm{e}^{0.0043 \mathrm{MEI}}, \mathrm{r}^{2}=0.99 ;$ Nellore $\times$ Angus $>$ BW $\left(\mathrm{kcal} / \mathrm{kgEBW}^{0.75} /\right.$ day $)=76.607 \mathrm{e}^{0.0035 \mathrm{MEI}}$, $\mathrm{r}^{2}=0.91$; Nellore $\times$ Simmental $>$ BW $\left(\mathrm{kcal} / \mathrm{kgEBW}^{0.75} /\right.$ day $)=$ $71.233 \mathrm{e}^{0.0039 \mathrm{MEI}}, \mathrm{r}^{2}=0.92$.

From the intercepts of equations above the daily net requirements of energy for maintenance of $65.27,76.61$ and

Table 3 - Requirements of net energy for gain (NEg, Mcal/kgEBWg/day) in animals from different genetic groups and combined by different body weight (BW)

\begin{tabular}{lccc}
\hline BW $(\mathrm{kg})$ & Nellore $^{1}$ & ${\text { Nellore } \times \text { Angus }^{2}}^{\text {Nellore } \times \text { Simmental }^{3}}$ \\
\hline 250 & 4.08 & 3.41 & 3.81 \\
300 & 4.58 & 3.81 & 4.34 \\
350 & 5.06 & 4.18 & 4.84 \\
400 & 5.51 & 4.53 & 5.32 \\
450 & 5.95 & 4.86 & 4.13 \\
\hline
\end{tabular}

${ }^{1}$ Nellore: $\mathrm{EBW}=0.91 \times \mathrm{BWF} / \mathrm{NEg}=0.076 \times 1.6424 \times \mathrm{EBW}^{0.6424}$.

2 Nellore $\times$ Angus: $\mathrm{EBW}=0.90 \times \mathrm{BWF} / \mathrm{NE}=0.082 \times 1.6015 \times \mathrm{EBW}^{0.6015}$

${ }^{3}$ Nellore $\times$ Simmental: $\mathrm{EBW}=0.91 \times \mathrm{BWF}_{\mathrm{g}} \mathrm{NE}_{\mathrm{g}}=0.048 \times 1.7075 \times \mathrm{EBW}^{0.7075}$

${ }^{4}$ Combined: $\mathrm{EBW}=0.91 \times \mathrm{BWF} ; \mathrm{NE}_{\mathrm{g}}=0.204 \times 1.4566 \times \mathrm{EBW}^{0.4566}$.

EBW - empty body weight; BWF - body weight at fast. 
$71.23 \mathrm{kcal} / \mathrm{kgEBW} .75 /$ day for Nellore, Nellore $\times$ Angus and Nellore $\times$ Simmental animals, respectively, were found. The identity test between models found no effect $(\mathrm{P}>0.05)$ of genetic group on the net requirements of energy for maintenance. Therefore, the use of a combined equation can be recommended for all genetic groups (Figure 2).

The average net energy requirement for maintenance was $70.55 \mathrm{kcal} / \mathrm{kgEBW}^{0.75} /$ day. The NRC (2000) advocates the value of $77 \mathrm{kcal} / \mathrm{kgEBW}^{0.75} /$ day as net requirement for maintenance and mentions that zebu animals would have about $10 \%$ below this energy requirement or $69.3 \mathrm{kcal} /$ $\mathrm{kgEBW}^{0.75} /$ day. It can be seen that the value found in this study is consistent with that proposed by NRC (2000).

Observing the percentages of organs plus viscera (Table 4), one could expect that Nellore $\times$ Angus animals would present higher net energy requirement for maintenance, once, according to Sainz et al. (1997), the size of visceral organs contributes to explaining differences in net energy requirements for maintenance of genetic groups. However, synthesis and protein degradation occurring in the organs and viscera represent $42 \%$ of the energy used by the gastrointestinal tract (Baldwin, 1995), i.e., such degradation is of great importance in energy requirements for maintenance.

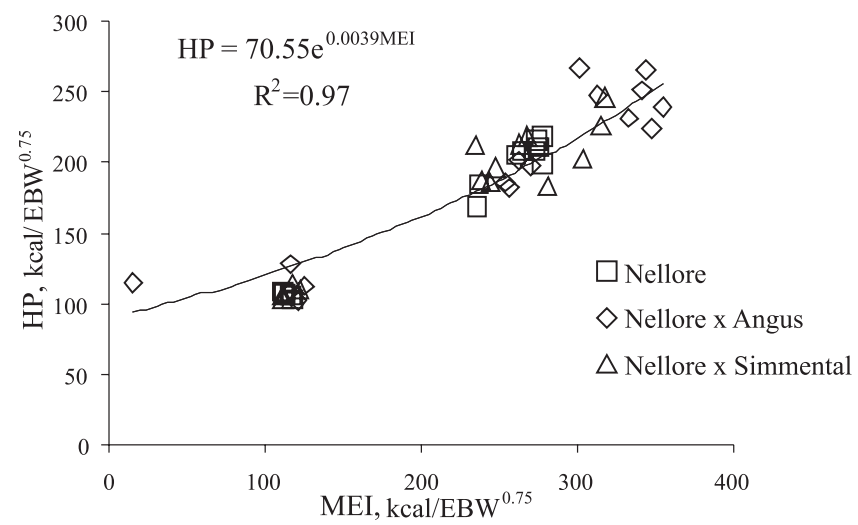

Figure 2 - Ratio between heat production (HP) and metabolizable energy intake (MEI).
Since there was no significant difference $(\mathrm{P}>0.05)$ between genetic groups in the participation of protein contained in the organs and viscera (Table 4 ), it is consistent that net energy requirements for maintenance are similar between genetic groups. According to Owens et al. (1995), internal fat, by being metabolically more active, requires increased energy spent and maintenance for deposition, i.e., the amount of such lipids directly influences on energy requirements for maintenance. Once there was no difference in the amount of such fat between genetic groups (Table 4), it may have contributed to there being no difference in net energy spent for maintenance.

The metabolizable energy requirement for maintenance can be defined as the metabolizable energy intake when retained energy is zero (Dawson \& Steen, 1998). Models developed for each genetic group had metabolizable energy requirement for maintenance of $85.37,94.68$ and $98.3 \mathrm{kcal} / \mathrm{kgEBW}^{0.75} /$ day for Nellore, Nellore $\times$ Angus and Nellore $\times$ Simmental animals. However, the identity test of models found no significant difference $(\mathrm{P}>0.05)$ between them. Thus, a combined equation was developed (Figure 3).

According to the combined model, daily metabolizable energy requirement for maintenance of animals is

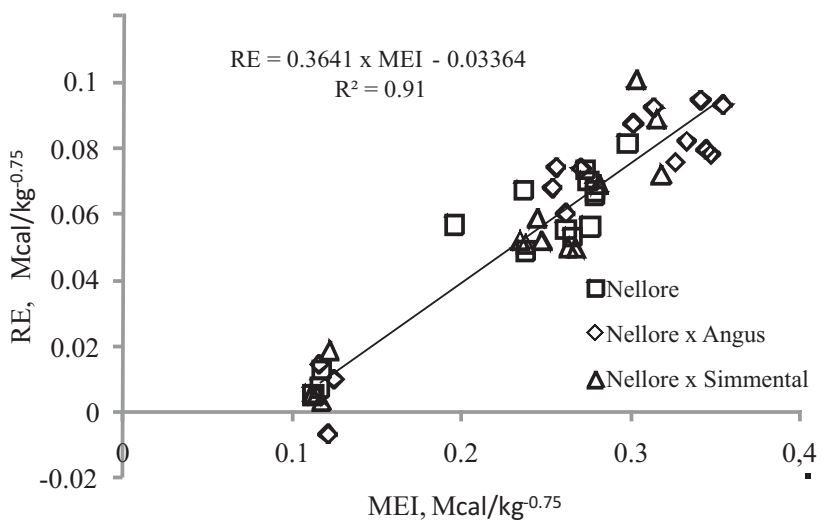

Figure 3 - Ratio between retained energy (RE) and metabolizable energy intake (MEI).

Table 4 - Participation of organs and viscera and their protein content and, internal fat of females of Nellore, $\mathrm{F}_{1}$ Nellore $\times$ Angus and $\mathrm{F}_{1}$ Nellore $\times$ Simmental

\begin{tabular}{|c|c|c|c|c|}
\hline \multirow[t]{2}{*}{ Item } & \multicolumn{3}{|c|}{ Genetic group } & \multirow[t]{2}{*}{$\mathrm{P}$ value } \\
\hline & Nellore & Nellore $\times$ Angus & Nellore $\times$ Simmental & \\
\hline Organs + viscera, \% EBW & $15.66 \mathrm{~b}$ & $16.92 \mathrm{a}$ & $15.70 \mathrm{~b}$ & 0.0165 \\
\hline Protein organs + viscera, $\%$ EBW & 1.44 & 1.65 & 1.56 & 0.3072 \\
\hline Protein organs + viscera, $\%$ TBP & 8.86 & 10.07 & 9.32 & 0.3586 \\
\hline Internal fat ${ }^{1}, \% \mathrm{EBW}$ & 5.74 & 5.43 & 5.07 & 0.0886 \\
\hline
\end{tabular}

Means followed by different letters in the same row differ significantly by Tukey test at $5 \%$ probability.

EBW - empty body weight; TBP - total body protein.

${ }^{1}$ Perirenal plus mesenteric fat. 
$92.38 \mathrm{kcal} / \mathrm{kgEBW}^{0.75} / \mathrm{day}$. This value is close to the 98.97 and $97.71 \mathrm{kcal} / \mathrm{kgEBW}^{0.75} /$ day found by Marcondes et al. (2011) and Freitas et al. (2006) respectively, working on males of the same genetic groups used in this study.

Using the slope of the generated model (Figure 3), there is an efficient use of metabolizable energy for weight gain $(\mathrm{kg})$ of $36.41 \%$. Performance data for each genetic group were $35.47,36.69$ and $37.33 \%$ for Nellore, Nellore $\times$ Angus and Nellore $\times$ Simmental, respectively. However, they did not differ in the identity test $(\mathrm{P}>0.05)$, so the average efficiency value was used for the three genetic groups (36.41\%).

The efficiency of using metabolizable energy for weight gain found in this study was lower than the $45 \%$ found by Marcondes et al. (2009), working on Nellore of three sex classes (integrate males, castrated males and females). Tedeschi et al. (2002) found values of 45.9 and $49.7 \%$ for castrated and integrated males of Nellore, respectively. However, efficiency values found in this study are consistent with Valadares Filho et al. (2006). These authors divide efficiency according to the diet received by animals; the $\mathrm{kg}$ would be $35 \%$ for animals receiving less than $50 \%$ concentrate and $47 \%$ for animals fed on more than $50 \%$ concentrate.

By the iterative method, metabolizable energy requirements for maintenance were estimated at the point where heat production matched the metabolic energy intake. MEm values for Nellore, Nellore $\times$ Angus and Nellore $\times$ Simmental animals were 99.22,110.09 and 106.25 $\mathrm{kcal} / \mathrm{kgEBW}^{0.75} /$ day. However, there was no significant difference $(\mathrm{P}>0.05)$ between genetic groups. Thus, the mean value $106.53 \mathrm{kcal} / \mathrm{kgEBW}^{0.75} /$ day was adopted for all groups.

Knowing the values of metabolizable and net energy for maintenance, there is the use efficiency of metabolizable energy for maintenance $(\mathrm{km})$. Km values obtained for Nellore, Nellore $\times$ Angus and Nellore $\times$ Simmental animals were 65.78 (65.27/99.22), $69.59(76.61 / 110.09)$ and 67.04
$(7.23 / 106.25) \%$. However, since there was no significant difference between these values, it is recommended to adopt the combined value of $66.23(70.55 / 106.53) \%$ for the three genetic groups.

Ferrell \& Jenkins (1998), evaluating taurine and their crosses, suggested efficiencies between 65 and $69 \%$, which are consistent with this study. According to the NRC (2000) and Valadares Filho et al. (2006), using the same iterative process, the recommended $\mathrm{km}$ values are 65 and $63 \%$ respectively.

From the combined data analysis, net energy requirements, metabolizable energy and total digestible nutrients for maintenance of Nellore, Nellore $\times$ Angus, Nellore $\times$ Simmental animals were estimated (Table 5) However, as there was no significant difference between these values, it is recommended to adopt the combined value of $66.23(70.55 / 106.53) \%$ for the three genetic groups.

The efficiency with which energy is used for synthesis of protein and fat can be measured through the multiple regression equation of the metabolizable energy intake (Mcal $/ \mathrm{kg} \mathrm{EBW}^{0.75} /$ day) as function of energy retained as protein $\left(\mathrm{RE}_{\text {prot }}, \mathrm{Mcal} / \mathrm{kg} \mathrm{EBW} \mathrm{E}^{0.75} /\right.$ day) and as fat $\left(\mathrm{RE}_{\mathrm{fat}}\right.$, Mcal $/ \mathrm{kg} \mathrm{EBW}^{0.75} /$ day) (Valadares Filho et al., 2005): $\mathrm{MEI}=0.131+6.08+\mathrm{RE}_{\text {prot }}+1.30 \mathrm{RE}_{\text {fat }}$.

The intercept represents the estimate of metabolizable energy requirement for maintenance $\left(131.0 \mathrm{kcal} / \mathrm{EBW}^{0.75} /\right.$ day). However, the use of this model overestimates the daily metabolizable energy requirements for maintenance, since it does not use animals in maintenance. Partial efficiency values of metabolizable energy use for synthesis of protein (kprot) and fat (kfat) were obtained by reversing the coefficients of the models mentioned above. Thus, the use efficiency of metabolizable energy for synthesis of protein and fat was $16.45(1 / 6,08)$ and $76.92 \%(1 / 1,30)$, respectively.

Estimates of kprot and kfat found in this study are consistent with values found in the literature. Marcondes et al. (2009) found $22.88 \%$ for kprot and $66.67 \%$ for kfat,

Table 5 - Net energy requirements $(\mathrm{mNE})$, metabolizable energy $\left(\mathrm{ME}_{\mathrm{m}}\right)$ total digestible nutrients (TDN) for maintenance of cattle Nellore, Nellore $\times$ Angus and Nellore $\times$ Simmental

\begin{tabular}{lccc}
\hline $\mathrm{BW}(\mathrm{kg})^{1}$ & $\mathrm{mNE}(\mathrm{Mcal} / \mathrm{day})^{2}$ & $\mathrm{ME}_{\mathrm{m}}(\mathrm{Mcal} / \mathrm{day})^{3}$ & $\mathrm{TDN}(\mathrm{kg})^{4}$ \\
\hline 250 & 4.13 & 6.24 & 1.73 \\
300 & 4.74 & 7.15 & 1.98 \\
350 & 8.08 & 2.22 & 2.46 \\
400 & 5.88 & 8.88 & 2.76 \\
450 & 6.42 & 9.70 & 2.68 \\
\hline
\end{tabular}

BW - body weight; EBW - empty body weight; BWF - body weight at fast.

${ }^{1} \mathrm{EBW}=0.91 \times \mathrm{BWF}$

$2 \mathrm{mNE}=70.55 \mathrm{kcal} / \mathrm{kgEBW}^{0.75} / \mathrm{day}$.

${ }^{3} \mathrm{ME}_{\mathrm{m}}=106.53 \mathrm{kcal} / \mathrm{kgEBW}^{0.75} /$ day.

${ }^{4}$ Considering the NRC protocol (2000). 
Chizzotti et al. (2008) found 34\% and 79\% for kprot and kfat, Owens et al. (1995) reported $47 \%$ and $79 \%$ for kprot and kfat and Valadares Filho et al. (2005) found 25 and $75 \%$ for kprot. and kfat respectively. The animal physiological state and nutritional status directly influences lipid and protein metabolism, so it is consistent to find a wide variation in use efficiencies of metabolizable energy for synthesis of protein and fat. Ferrell (1984) reports 10 to $40 \%$ for kprot. and 60 to $80 \%$ for kfat.
From the results found in this study, energy requirements for Nellore, Nellore $\times$ Angus and Nellore $\times$ Simmental animals with different body weights and average daily gains were estimated (Table 6). One can notice that the higher the body weight and growth rate, regardless of how the energy requirements being expressed, the higher the energy requirements. This behavior is plausible, since the increase in growth rate results in increased adipose tissue deposition in the animal.

Table 6 - Total requirements of energy (maintenance + body weight gain) and total digestible nutrients for Nellore heifers of their crossings

\begin{tabular}{|c|c|c|c|c|c|c|c|c|c|c|c|c|}
\hline & \multicolumn{3}{|c|}{ Nellore } & \multicolumn{3}{|c|}{ Nellore $\times$ Angus } & \multicolumn{3}{|c|}{ Nellore $\times$ Simmental } & \multicolumn{3}{|c|}{ Combined } \\
\hline & 0.5 & 1.0 & 1.5 & 0.5 & 1.0 & 1.5 & 0.5 & 1.0 & 1.5 & 0.5 & 1.0 & 1.5 \\
\hline & & \multicolumn{11}{|c|}{ Net energy (Mcal/day) } \\
\hline 250 & 5.76 & 7.87 & 10.06 & 6.00 & 7.69 & 9.43 & 5.73 & 8.09 & 10.88 & 5.81 & 7.79 & 9.91 \\
\hline 300 & 6.60 & 9.02 & 11.53 & 6.88 & 8.81 & 10.82 & 6.57 & 9.27 & 12.48 & 6.66 & 8.93 & 11.36 \\
\hline 350 & 7.41 & 10.13 & 12.94 & 7.72 & 9.89 & 12.14 & 7.38 & 10.41 & 14.00 & 7.47 & 10.03 & 12.75 \\
\hline 400 & 8.19 & 11.20 & 14.31 & 8.53 & 10.93 & 13.42 & 8.16 & 11.51 & 15.48 & 8.26 & 11.08 & 14.10 \\
\hline & \multicolumn{12}{|c|}{ Metabolizable energy (Mcal/day) } \\
\hline 250 & 11.27 & 17.22 & 23.39 & 10.61 & 15.21 & 19.98 & 10.41 & 16.72 & 24.19 & 10.84 & 16.28 & 22.11 \\
\hline 300 & 12.92 & 19.75 & 26.81 & 12.16 & 17.44 & 22.90 & 11.93 & 19.17 & 27.74 & 12.42 & 18.67 & 25.34 \\
\hline 350 & 14.50 & 22.17 & 30.10 & 13.66 & 19.58 & 25.71 & 13.39 & 21.52 & 31.14 & 13.95 & 20.96 & 28.45 \\
\hline 400 & 16.03 & 24.50 & 33.27 & 15.09 & 21.64 & 28.42 & 14.80 & 23.78 & 34.42 & 15.41 & 23.16 & 31.45 \\
\hline \multicolumn{13}{|c|}{ Total digestible nutrients ( $\mathrm{kg} /$ day) } \\
\hline 250 & 3.12 & 4.76 & 6.47 & 2.93 & 4.21 & 5.53 & 2.88 & 4.62 & 6.69 & 3.00 & 4.50 & 6.11 \\
\hline 300 & 3.57 & 5.46 & 7.42 & 3.36 & 4.82 & 6.33 & 3.30 & 5.30 & 7.67 & 3.44 & 5.16 & 7.01 \\
\hline 350 & 4.01 & 6.13 & 8.33 & 3.78 & 5.42 & 7.11 & 3.70 & 5.95 & 8.61 & 3.86 & 5.80 & 7.87 \\
\hline 400 & 4.43 & 6.78 & 9.20 & 4.18 & 5.99 & 7.86 & 4.09 & 6.58 & 9.52 & 4.26 & 6.41 & 8.70 \\
\hline
\end{tabular}

NE·EBW $=0.91 \times$ BWF; NA:EBW $=0.90 \times$ BWF; NS:EBW $=0.91 \times$ BWF; Combined $: E B W=0.91 \times$ BWF; Combined:EBWg $=0.91 \times$ ADG. NE:NEm $=65.27 \mathrm{kcal} /$ $\mathrm{kgEBW}^{0.75} / \mathrm{day} ; \mathrm{NA}: \mathrm{NE}_{\mathrm{m}}=76.61 \mathrm{kcal} / \mathrm{kgEBW}^{0.75} / \mathrm{day} ; \mathrm{NS}: \mathrm{NE}_{\mathrm{m}}=71.23 \mathrm{kcal} / \mathrm{kgEBW}^{0.75} / \mathrm{day} ;$ Combined $: \mathrm{EL}_{\mathrm{m}}=70.55 \mathrm{kcal} / \mathrm{kgEBW}^{0.75} / \mathrm{day} . \mathrm{NE} \mathrm{ME}_{\mathrm{m}}=99.22 \mathrm{kcal} /$ $\mathrm{kgEBW}^{0.75} / \mathrm{day} ; \mathrm{NA}: \mathrm{ME}_{\mathrm{m}}=110.09 \mathrm{kcal} / \mathrm{kgEBW}^{0.75} /$ day; NS: $\mathrm{ME}_{\mathrm{m}}=106.25 \mathrm{kcal} / \mathrm{kgEBW}^{0.75} / \mathrm{day} ;$ Combined: $\mathrm{ME}_{\mathrm{m}}=106.53 \mathrm{kcal} / \mathrm{kgEBW}$. $\mathrm{NA}: \mathrm{km}=69.59 \% ; \mathrm{NS}: \mathrm{km}=67.04 \% ;$ Combined $: \mathrm{km}=66.23 \% ; \mathrm{NE}: \mathrm{kg}=35.47 \% ; \mathrm{NA}: \mathrm{kg}=36.69 \% ; \mathrm{NS}: \mathrm{kg}=37.33 \% ;$ Combined $: \mathrm{kg}=36.41 \% . \mathrm{NE}: \mathrm{RE}(\mathrm{Mcal} / \mathrm{day})=0.0773$ $\times \mathrm{EBW}^{0.75} \times \mathrm{EBWg}^{1.063} ; \mathrm{NA}: \mathrm{RE}(\mathrm{Mcal} / \mathrm{day})=0.0623 \times \mathrm{EBW}^{0.75} \times \mathrm{EBWg}^{1.065} ; \mathrm{NS}: \mathrm{RE}(\mathrm{Mcal} / \mathrm{day})=0.0769 \times \mathrm{EBW}^{0.75} \times \mathrm{EBWg}^{1.327} ; \mathrm{Combined}: \mathrm{RE}(\mathrm{Mcal} / \mathrm{day})=0.0703$ $\times \mathrm{EBW}^{0.75} \times \mathrm{EBWg}^{1.128}$. TDN was estimated according to the NRC protocol $(2000)$

NE - Nellore; NS - Nellore $\times$ Simmental; NA - Nellore $\times$ Angus; EBW- empty body weight; EBWg - empty body weight gain; BWF - body weight at fast; ADG - average daily gain; $\mathrm{ME}_{\mathrm{m}}$ - Metabolizable energy of maintenance; NEm - Net energy of maintenance; RE - retained energy.

\section{Conclusions}

The combined equation RE (Mcal/day) $=0.0703 \times$ $\mathrm{EBW}^{0.75} \times \mathrm{EBWg}^{1.128}$ is recommended to predict net energy requirements for weight gain of females in Nellore, $\mathrm{F}_{1}$ Nellore $\times$ Angus and $\mathrm{F}_{1}$ Nellore $\times$ Simmental animals. The net energy requirement for maintenance of females in Nellore, $\mathrm{F}_{1}$ Nellore $\times$ Angus and $\mathrm{F}_{1}$ Nellore $\times$ Simental cattle is $70.55 \mathrm{kcal} / \mathrm{kgEBW}^{0.75} /$ day and metabolizable energy requirement for maintenance is $106.53 \mathrm{kcal} / \mathrm{kgEBW}^{0.75} /$ days. The use efficiencies of metabolizable energy for gain and maintenance are 36.41 and $66.23 \%$ for the three genetic groups, respectively.

\section{References}

AGRICULTURAL RESEARCH COUNCIL - ARC. The nutrient requirements of ruminants livestock. London: 1980. $351 \mathrm{p}$.
BACKES, A.A.; SANCHEZ, L.M.B.; GONCALVES, M.B.F. et al. Composição corporal e exigências líquidas de energia e proteína para ganho de peso de novilhos santa gertrudis Revista Brasileira de Zootecnia, v.31, n.6, p.2307-2313, 2002.

BALDWIN, R.L. Modeling ruminant digestion and metabolism. London: Chapman and Hall, 1995. 592p.

BERNDT, A.; HENRIQUE, W.; LEME, P.R. et al. Exigências líquidas de proteína e energia para crescimento de tourinhos Santa Gertrudis em rações de alto teor de concentrado. Revista Brasileira de Zootecnia, v.31, n.5, p.2098-2104, 2002.

CATON, J.S.; BAUER, M.L.; HIDDARI, H. Metabolic components of energy expenditure in growing beef catlle - review. Asian-Australasian Journal of Animal Science, v.13, n 5, p.702-710, 2000.

CHIZZOTTI, M.L.; TEDESCHI, L.O.; VALADARES FILHO, S.C. A meta-analysis of energy and protein requirements for maintenance and growth of Nellore cattle. Journal of Animal Science, v. 86, n.7, p.1588-1597, 2008.

COUTINHO FILHO, J.L.V.; PERES, R.M.; JUSTO, C.L. Produção de carne de bovinos contemporâneos, machos e fêmeas, terminados em confinamento. Revista Brasileira de Zootecnia, v.35, n.5, p.2043-2049, 2006.

DAWSON, L.E.R.; STEEN, R.W.J. Estimation of maintenance energy requirements of beef cattle and sheep. Journal of Agriculture Science, v.131, p.477-485, 1998. 
FERRELL, C.L. Sources of variation in animal energy expenditures. In: INTERNACIONAL WORKSHOP ON MODELLING OF RUMINANT DIGESTION AND METABOLISM, 2., 1984, Davis. Proceedings... Davis: University of California, 1984. p.100-105.

FERRELL, C.L.; JENKINS, T.G. Body composition and energy utilization by steers of diverse genotypes fed a high-concentrate diet during the finishing period: I. Angus, Belgian Blue, Hereford, and Piedmontese Sires. Journal of Animal Science, v.76, p.637-646, 1998.

FREITAS, J.A.; QUEIROZ, A.C.; DUTRA, A.R. et al. Eficiência de utilização da energia metabolizável em bovinos Nelore puros e cruzados submetidos a quatro níveis de concentrado na ração. Revista Brasileira de Zootecnia, v.35, n.3, p.894-901, 2006.

FULLER, W.A. Measurement error models. New York: John Wiley and Sons, 1987. 440p.

HALL, M.B. Calculation of non-structural carbohydrate content of feeds that contain non-protein nitrogen. Gainesville: University of Florida, 2000. p.A-25 (Bulletin, 339).

HALL, M.B.; HOOVER, W.H.; JENNINGS, J.P. et al. A Method for partitioning neutral detergent soluble carbohydrates. Journal Science Food Agriculture, v.79, n.9 p.2079-2086, 1999.

LUCHIARI FILHO, A. A pecuária da carne bovina. São Paulo: Albino Luchiari Filho, 2000. 134p.

MARCONDES, M.I.; VALADARES FILHO, S.C.; PAULINO, P.V.R. et al. Exigências nutricionais de proteína, energia e macrominerais de bovinos Nelore de três classes sexuais. Revista Brasileira de Zootecnia, v.38, n.8, p.1587-1596, 2009.

MARCONDES, M.I.; VALADARES FILHO, S.C.; PAULINO, M.F. et al. Exigência de energia de animais Nelore puros e cruzados com as raças Angus e Simental. Revista Brasileira de Zootecnia, v.40, n.4, p.872-881, 2011.

NATIONAL RESEARCH COUNCIL - NRC. Nutrients requirements of beef cattle. 7.ed. Washington, D.C.: 2000. 242p.

OWENS, F.N.; GILL, D.R.; SECRIS, D.S. et al. Review of some aspects of growth and development of feedlot cattle. Journal of Animal Science, v.73, p.3152-3172, 1995.

PAULINO, M.F.; FONTES, C.A.A.; JORGE, A.M. et al. Exigências de energia para mantença de bovinos zebuínos não-castrados em confinamento. Revista Brasileira de Zootecnia, v.28, n.3, p.621-626, 1999 .
PAULINO, P.V.R.; COSTA, M.A.L.; VALADARES FILHO, S.C. et al. Exigências Nutricionais de Zebuínos. Energia Revista Brasileira de Zootecnia, v.33, n.3, p.781-791, 2004.

REGAZZI, J.A. Teste para verificar a identidade de modelos de regressão. Pesquisa Agropecuária Brasileira, v.31, n.1, p.117,1996

SAINZ, R.D.; BENTLEY, B.E. Visceral organ mass and cellularity in growth-restricted and refed beef steers. Journal of Animal Science, v.75, p.1229-1236, 1997.

SILVA, D.J.; QUEIROZ, A.C. Análise de alimentos (métodos químicos e biológicos). 3.ed. Viçosa, MG: Imprensa Universitária, Universidade Federal de Viçosa, 2002. 165p.

SILVA, F.F.; VALADARES FILHO, S.C.; ÍTAVO, L.C. et al. Exigências líquidas e dietéticas de energia, proteína e macroelementos minerais de bovinos de corte no Brasil. Revista Brasileira de Zootecnia, v.31, n.2, p.776-792, 2002.

SIQUEIRA, J.G.; FONTES, C.A.A.; PEREIRA, A.L. et al. Exigência de energia de mantença e composição corporal e do ganho de vacas de corte adultas de três grupos genéticos confinadas. Revista Brasileira de Zootecnia, v.36, n.6, p.2159-2167, 2007.

TEDESCHI, L.O.; BOIN, C.; FOX, D.G. et al. Energy requirement for maintenance and growth of Nellore bulls and steers fed high-forage diets. Journal of Animal Science, v.80, n.6, p.1671-1682, 2002.

VALADARES FILHO, S.C.; MARCONDES, M.I.; CHIZZOTTI, M.L. et al. Exigências nutricionais de zebuínos puros e cruzados BR CORTE. 2.ed. Viçosa, MG: UFV, Suprema Gráfica Ltda. 2010. $193 \mathrm{p}$.

VALADARES FILHO, S.C.; PAULINO, P.V.R.; MAGALHÃES, K.A Exigências nutricionais de zebuínos e tabelas de composição de alimentos - BR CORTE. Viçosa, MG: UFV, Suprema Gráfica Ltda. 2006. 142p.

VALADARES FILHO, S.C.; PAULINO, P.V.R.; SAINZ, R.D. Desafios metodológicos para determinação das exigências nutricionais de bovinos de corte no Brasil. In: REUNIÃO ANUAL DA SOCIEDADE BRASILEIRA DE ZOOTECNIA, 42., 2005, Goiânia. Anais... Goiânia: Sociedade Brasileira de Zootecnia, 2005. p.261-287.

WEISS, W.P. Energy prediction equations for ruminant feeds Cornell: Nutrition conference for feed manufactures, 1999. p. $176-185$. 